\title{
Metabolism of Chicken Feathers and Concomitant Electricity Generation by Pseudomonas aeruginosa by Employing Microbial Fuel Cell (MFC)
}

\author{
Venkatesh Chaturvedi ${ }^{1}$ and Pradeep Verma ${ }^{2}$ \\ ${ }^{1}$ School of Biotechnology, Banaras Hindu University, Varanasi 221005, India \\ ${ }^{2}$ Department of Microbiology, Central University of Rajasthan, NH-8, Bandarsindri, Kishangarh, Ajmer Rajasthan 305801, India \\ Correspondence should be addressed to Pradeep Verma; vermaprad@yahoo.com
}

Received 17 September 2013; Accepted 10 December 2013; Published 9 January 2014

Academic Editor: Dimitris P. Makris

Copyright (c) 2014 V. Chaturvedi and P. Verma. This is an open access article distributed under the Creative Commons Attribution License, which permits unrestricted use, distribution, and reproduction in any medium, provided the original work is properly cited.

\begin{abstract}
Keratinolytic potential of Pseudomonas aeruginosa strain SDS3 has been evaluated for the metabolism of chicken feathers. Results indicated that strain SDS3 showed complete metabolism of 0.1 and $0.5 \%(\mathrm{w} / \mathrm{v})$ chicken feathers in minimal medium. Feathers were metabolized up to $80 \%$ at $1 \%(\mathrm{w} / \mathrm{v})$ concentration. Maximum soluble protein $(480.8 \pm 17.1 \mu \mathrm{g} / \mathrm{mL})$ and keratinase $(15.4 \pm 0.25 \mathrm{U} / \mathrm{mL})$ were observed in the presence of $1 \%$ chicken feathers after five days of incubation. The effect of carbon and nitrogen sources showed that feather degradation was stimulated by complex carbon/nitrogen sources such as starch, malt extract, tryptone, and beef extract and was inhibited by simple carbon and nitrogen sources. Electricity production by employing chicken feathers as a substrate in microbial fuel cell (MFC) was evaluated. It was observed that maximum voltage corresponding to $141 \mathrm{mV}$ was observed after 14 days of incubation. Maximum power density of $1206.78 \mathrm{~mW} / \mathrm{m}^{2}$ and maximum current density of $8.6 \mathrm{~mA} / \mathrm{m}^{2}$ were observed. The results clearly indicate that chicken feathers can be successfully employed as a cheap substrate for electricity production in MFC. This is the first report showing employment of chicken feathers as substrate in MFC.
\end{abstract}

\section{Introduction}

Feathers constitute the major bulk of biological waste generated by local butchers and poultry processing industries in India [1]. According to a recent report of USDA, annual consumption of poultry in India was 2.3 million tons in 2010 and it is expected to increase at a tremendous rate. Due to poor management of waste, the by-products of poultry industry (especially feathers) have become one of the major pollutants due to their recalcitrant nature $[1,2]$. About $90 \%$ of feathers consist of keratin, which is a fibrous and insoluble structural protein consisting of $\beta$-helical coils joint together by disulfide linkages [3]. This structural feature enables it to resist adverse environmental conditions and degradation by proteases [4]. Therefore, feathers are considered as a biological waste and cause serious environmental problems. However, feathers are considered a good source of essential amino acids [5] but due to their stable structure, feathers cannot be employed as a source of proteins and free amino acids in their native form and requires processing to release amino acids and peptides [6]. The most commonly used method for feather disposal is incineration [7] and degradation by chemical methods [8]. These methods cause significant reduction in amino acid content of feathers and reduce the overall quality of proteins [7]. Biodegradation of feather by microorganisms such as bacteria and fungi is found to be an efficient and cost-effective method for bioconversion of feather waste into nutritionally useful feather lysate, which contains free amino acids, peptides, and ammonium ions $[4,6]$. The feather lysate can be further employed as protein rich meal for animals [6] or can be used as a source of nitrogenous fertilizers for plants [9].

Due to rapid industrialization, there has been a tremendous increase consumption of electricity and therefore many countries are facing global energy crisis [10]. The natural resources are rapidly depleting and there is a search for 
alternate sources of energy generation [11-13]. Microbial fuel cell (MFC) is an alternative approach which employs microorganisms for electricity production [14]. In this process, metabolism of organic compounds by microbes is coupled to electricity generation [11]. A wide range of organic compounds including compounds present in various types of wastes have been employed as a substrate in MFC's $[15,16]$. Use of these substances offers a dual advantage; the waste material is removed/degraded by microorganisms and it is coupled to electricity generation [17]. Chicken feathers are also considered as organic waste material having high $\mathrm{C} / \mathrm{N}$ ratio; therefore, it can be used for electricity generation in MFC because only carbon during its oxidation by microbes is responsible for electricity generation [14], whereas nitrogen present in organic waste does not play any role. High concentration of ammonium ions generated after metabolism of nitrogen containing organic compounds is often inhibitory to microorganisms [15-17]. In the present study, an attempt has been made for testing feather degrading potential of a sodium dodecyl sulfate (SDS) degrading strain of $P$. aeruginosa SDS3 [18]. Feather metabolism by strain SDS3 was evaluated by estimating growth, soluble protein, and keratinase during regular time interval. Effect of exogenous carbon and nitrogen sources on feather metabolism was also evaluated. Further, by employing microbial fuel cell (MFC) technology chicken feathers were used as a substrate in MFC for generation of bioelectricity using $P$. aeruginosa strain SDS3.

\section{Materials and Methods}

2.1. Strain and Culture Conditions. P. aeruginosa strain SDS3 (GenBank accession no. EF197939) was isolated from a detergent contaminated pond situated in Varanasi city, India [18]. This strain was recovered by employing enrichment technique in minimal medium phosphate buffered medium (PBM) supplemented by SDS as a source of carbon. This strain was grown on casein agar medium to study proteolytic activity. Casein agar medium contained the following $(\mathrm{g} / \mathrm{L})$ : $\mathrm{K}_{2} \mathrm{HPO}_{4} 0.3, \mathrm{KH}_{2} \mathrm{PO}_{4} 0.4, \mathrm{NaCl} 0.5, \mathrm{MgCl}_{2} \cdot 6 \mathrm{H}_{2} \mathrm{O} 0.1$, and casein 10 in distilled water ( $\mathrm{pH} 7.5)$. Keratinolytic potential was studied following growth on feather meal broth (FMB). The medium contained the following $(\mathrm{g} / \mathrm{L}): \mathrm{K}_{2} \mathrm{HPO}_{4} 0.3$, $\mathrm{KH}_{2} \mathrm{PO}_{4} 0.4, \mathrm{NaCl} 0.5, \mathrm{MgCl}_{2} \cdot 6 \mathrm{H}_{2} \mathrm{O} 0.1$, and feather 10 [19]. The $\mathrm{pH}$ was adjusted to 7.5 prior to sterilization. For subculturing and storing, feather meal agar (FMA) was employed, which contained (g/L) $\mathrm{K}_{2} \mathrm{HPO}_{4} 0.3, \mathrm{KH}_{2} \mathrm{PO}_{4}$ $0.4, \mathrm{NaCl} 0.5, \mathrm{MgCl}_{2} \cdot 6 \mathrm{H}_{2} \mathrm{O} 0.1$, feather 10, and agar 15 . Chicken feathers were obtained from a local butcher. They were washed extensively with tap water, dried at $60^{\circ} \mathrm{C}$ for 2 days, and then kept at $4^{\circ} \mathrm{C}$ until used. All the media were autoclaved at $121^{\circ} \mathrm{C}, 105 \mathrm{kPa}$ for $30 \mathrm{~min}$. For inoculum preparation, tryptone water was employed, which contained the following tryptone $10 \mathrm{~g}, \mathrm{NaCl} 5 \mathrm{~g}, \mathrm{pH}-7.0$.

A single colony of strain SDS3 was inoculated in $50 \mathrm{~mL}$ of tryptone water contained in $250 \mathrm{~mL}$ of Erlenmeyer flasks and incubated at $30^{\circ} \mathrm{C}$ in an orbital shaker (125 rpm). After overnight growth, the culture was centrifuged at $8000 \mathrm{rpm}$ for
10 min in a Sorvall RC-5B superspeed refrigerated centrifuge (Du Pont Instruments, USA). The cell pellet was washed twice and suspended in $5 \mathrm{~mL}$ FMB (without feathers). 5\% (v/v) inoculums $\left(10^{8} \mathrm{CFU} / \mathrm{mL}\right)$ were added to $100 \mathrm{~mL}$ of $\mathrm{FMB}$ (containing varying amount of feather) and incubated at the same conditions. Samples $(2 \mathrm{~mL})$ were retrieved from each of triplicate cultures every $24 \mathrm{~h}$ to evaluate growth, soluble protein production, and enzyme activity. Triplicate assays were performed for each parameter.

2.2. Estimation of Growth. Growth was estimated using TTC reduction method and absorbance was measured at $480 \mathrm{~nm}$ [20]; briefly, to $1 \mathrm{~mL}$ of culture suspension $10 \mu \mathrm{L}$ of $0.02 \%$ TTC solution was added and was incubated at $30^{\circ} \mathrm{C}$ for $30 \mathrm{~min}$. The cell suspension was then centrifuged at $8000 \mathrm{rpm}$ for $10 \mathrm{~min}$ and supernatant was discarded. To the cell pellet $1 \mathrm{~mL}$ of $95 \%$ ethanol was added. The solution was vortexed to suspend the cell pellet. The solution was incubated for another $30 \mathrm{~min}$ and centrifuged at $8000 \mathrm{rpm}$ of $10 \mathrm{~min}$. The absorbance of supernatant was recorded at $480 \mathrm{~nm}$. A standard curve was prepared by diluting a culture of strain SDS3 grown for overnight in LB medium. Protein concentration was determined using Bradford method [21] and bovine serum albumin (BSA) used as standard. The protein concentration was determined spectrophotometrically at $590 \mathrm{~nm}$ using UV1800, UV-Vis Spectrophotometer (Shimadzu).

2.3. Preparation of Soluble Keratin and Azokeratin. Soluble keratin was prepared according to the method of Wawrzkiewicz et al. [22]. Azokeratin was synthesized based on the methodology described by Tomarelli et al. [23].

\subsection{Enzyme Production and Keratinase Assay. Strain SDS3} was grown in FMB containing $1 \%$ chicken feathers as described above. Samples $(2 \mathrm{~mL})$ were retrieved after $24 \mathrm{~h}$ interval and were centrifuged at 10,000 rpm for $5 \mathrm{~min}$ at $4^{\circ} \mathrm{C}$ in a Sorvall RC-5B superspeed refrigerated centrifuge (Du Pont Instruments, USA), and the supernatant was used as a crude enzyme preparation. Keratinase activity was assayed with azokeratin as a substrate by the following method of Daroit et al. [24]. The reaction mixture contained $200 \mu \mathrm{L}$ of enzyme preparation and $700 \mu \mathrm{L}$ of $10 \mathrm{~g}$ azokeratin/L in $50 \mathrm{mM}$ Tris buffer, $\mathrm{pH}$ 8.0. The reaction mixture was incubated for $30 \mathrm{~min}$ at $30^{\circ} \mathrm{C}$. The reaction was stopped by the addition of $100 \mu \mathrm{L}$ of $10 \%$ trichloroacetic acid (TCA) and reaction mixture was centrifugated at $10,000 \mathrm{rpm}$ for $5 \mathrm{~min}$ in a Sorvall RC-5B superspeed refrigerated centrifuge (Du Pont Instruments, USA); the absorbance of supernatant was determined at $440 \mathrm{~nm}$. One unit of enzyme activity was expressed as the amount of enzyme that caused a change of absorbance of 0.01 at $440 \mathrm{~nm}$ at $30^{\circ} \mathrm{C}$ for $30 \mathrm{~min}$. All the experiments were performed in triplicate and the results are expressed as mean \pm standard deviation.

2.5. Microscopic Study of Feather Degradation. Strain SDS3 was inoculated in FMB supplemented with 1\% feathers; after desired time intervals $(24 \mathrm{~h})$ feathers were removed aseptically and were stained with $0.1 \%$ safranin for $5 \mathrm{~min}$ to 


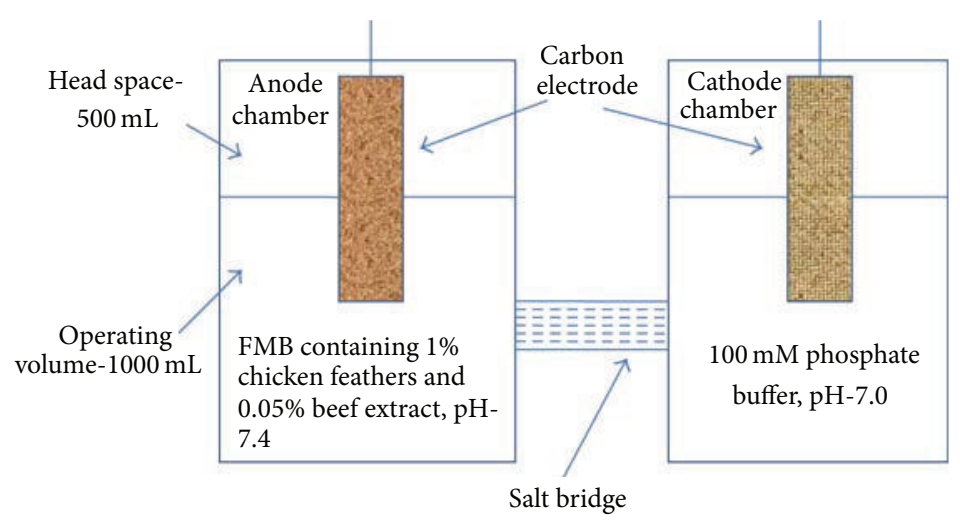

FIGURE 1: Schematic design of MFC connected with salt bridge.

provide contrast. The feathers were observed in a compound microscope at 10, 20x magnification (Nikon Eclipse E400, Nikon Corporation, Tokyo, Japan).

\subsection{Effect of Carbon and Nitrogen Sources on Growth, Soluble} Protein, and Keratinase Activity. The carbon sources (glucose, fructose, sucrose, maltose, lactose, galactose, mannitol, glycerol, and soluble starch) were provided at a concentration of $0.1 \%(\mathrm{w} / \mathrm{v})$ in FMB supplemented with $0.1 \%$ chicken feathers [25]. Different nitrogen sources (beef extract, casein, malt extract, skim milk, tryptone, yeast extract, urea, $\left(\mathrm{NH}_{4}\right)_{2} \mathrm{SO}_{4}$, $\mathrm{NH}_{4} \mathrm{Cl}, \mathrm{NH}_{4} \mathrm{NO}_{3}, \mathrm{NH}_{4} \mathrm{H}_{2} \mathrm{PO}_{4}, \mathrm{KNO}_{3}, \mathrm{NaNO}_{2}$, and $\mathrm{NaNO}_{3}$ ) were added separately to the medium at a concentration of $0.05 \%(w / v)$. After 4 days of incubation, the samples were retrieved and assayed for cell growth, soluble protein, and keratinase activity. All the experiments were performed in triplicate and the results are expressed as mean \pm standard deviation.

2.7. MFC and Its Operation. A dual chambered H-type MFC was designed consisting of two identical plastic containers (1500 mL capacity) [26]. Each chamber had an operating volume of $1000 \mathrm{~mL}$ and a head space of $500 \mathrm{~mL}$, respectively. The cathode and anode chambers were connected by a salt bridge (a plastic tube $(6 \mathrm{~cm})$ containing $1.5 \%$ agar and $3 \%$ $\mathrm{NaCl})$. Two identical carbon electrodes $(9 \times 1.75 \mathrm{~cm})$ were used as anode and cathode, respectively. The surface area of each electrode was $28.9 \mathrm{~cm}^{2}$. The surface area of cathode was increased to $82.34 \mathrm{~cm}^{2}$ by wrapping it with carbon cloth. A representation of MFC is shown in Figure 1. An external resistance of $2000 \Omega$ was used in all experiments and the potential across the resistor was recorded using the autorange digital multimeter. The anolyte solution was FMB containing $1 \%(\mathrm{w} / \mathrm{v})$ chicken feathers and $0.05 \%$ beef extract, $\mathrm{pH}-7.0$. The catholyte solution was $100 \mathrm{mM}$ phosphate buffer $(\mathrm{pH}$ 7). Catholyte and anolyte solutions were buffered to $\mathrm{pH}$ 7.0 using $100 \mathrm{mM}$ phosphate buffer in all experiments. The anolyte medium and all MFC components were sterilized by autoclaving. The experiments were carried out in batch mode with a working volume of $1000 \mathrm{~mL}$ in each MFC compartment. During start-up, the anolyte was inoculated with a growing culture of $P$. aeruginosa SDS3 (5\% of the total anolyte volume). The experiments were performed at $30^{\circ}$ in a BOD incubator.

\section{Results and Discussion}

3.1. Growth of P. aeruginosa SDS3 in the Presence of Raw Chicken Feathers. P. aeruginosa SDS3 produced halo zone on casein agar plate indicates production of proteases after $24 \mathrm{~h}$ of incubation (Figure 2(a)). In addition, the strain SDS3 also showed growth in the presence of feather meal broth supplemented with raw chicken feathers $(1 \mathrm{~g} / \mathrm{L})$ as a sole source of carbon and nitrogen. Feathers degradation was visible after $24 \mathrm{~h}$ of incubation and complete degradation was observed after $72 \mathrm{~h}$ of incubation (Figure 2(b)). Degradation of chicken feathers (Figure 3(a)) was studied microscopically which indicated that during initial period of growth, the barbules were degraded and barbs were visible (Figure 3(b)) but, during later period of growth, these barbs were also degraded (Figure 3(c)) and complete degradation of chicken feathers was observed after $72 \mathrm{~h}$ of incubation. During growth in the presence of feathers, an increase in $\mathrm{pH}$ of growth medium was also observed. The $\mathrm{pH}$ of growth medium increased from 7.5 to 8.6 during the course of degradation suggesting release of free amino acids in the growth medium after degradation of feathers. Many researchers have reported complete/partial degradation of native chicken feathers [19]. It indicates that bacterial and fungal strains exhibit varying keratinolytic potential. The strain SDS3 showed a slow rate of degradation as compared with $P$. aeruginosa strain KS-1, which showed high rates of feather degradation [27]. These differences can be attributed to metabolic versatility between isolates growing in different environmental conditions.

3.2. Growth in the Presence of Different Concentrations of Chicken Feathers. P. aeruginosa strain SDS3 was grown in the presence of $0.1,0.5$, and $1.0 \%(\mathrm{w} / \mathrm{v})$ of chicken feathers in FMB. Concentrations higher than $1.0 \%$ were not included because the feathers hindered the shaking and aeration of the medium, making the comparative study difficult. The strain SDS3 showed complete degradation of 0.1 and $0.5 \%$ of feathers after 3 and 5 days of incubation, respectively. However, at $1.0 \%$ feather concentration, the degradation was 


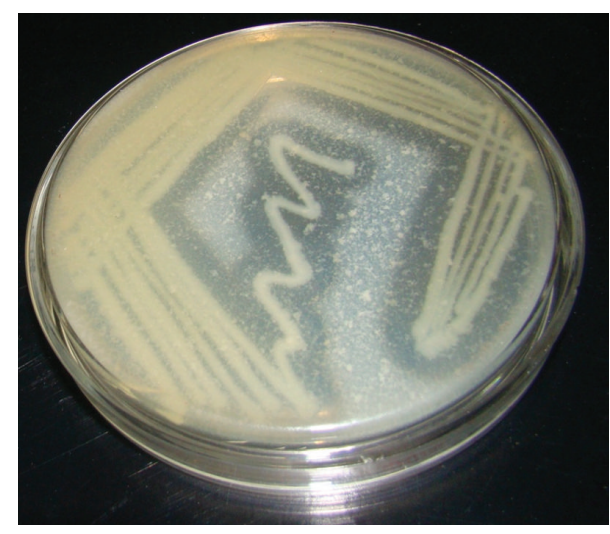

(a)

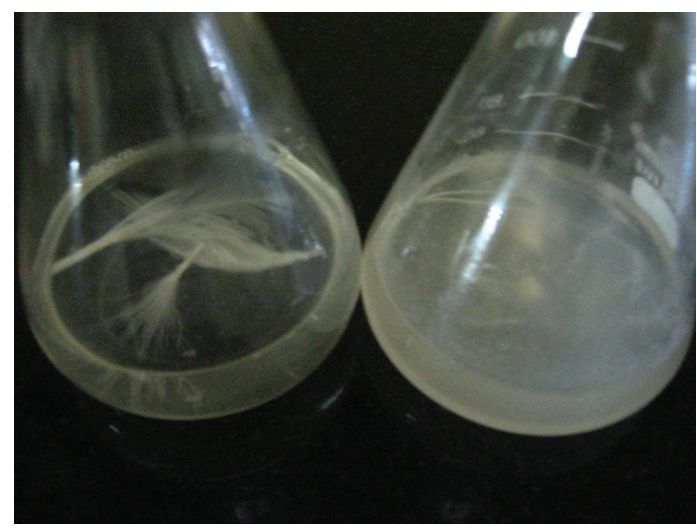

(b)

FIGURE 2: (a) Casein agar plate showing production of protease by $P$. aeruginosa strain SDS3. (b) Degradation of raw chicken feathers by strain SDS3 in FMB supplemented with $0.1 \%$ chicken feathers, incubated at $150 \mathrm{rpm}, 30^{\circ} \mathrm{C}$ after $72 \mathrm{~h}$ of incubation.

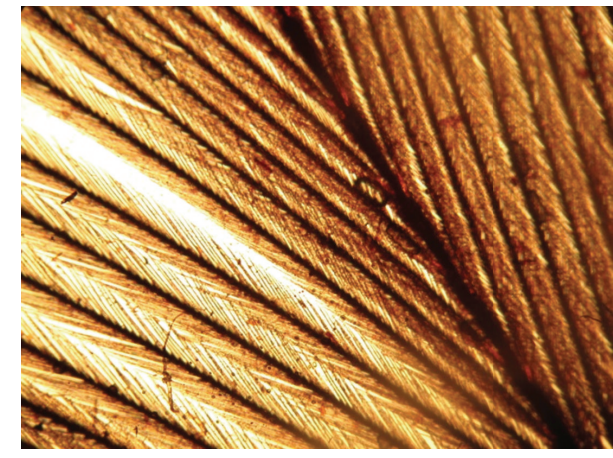

(a)

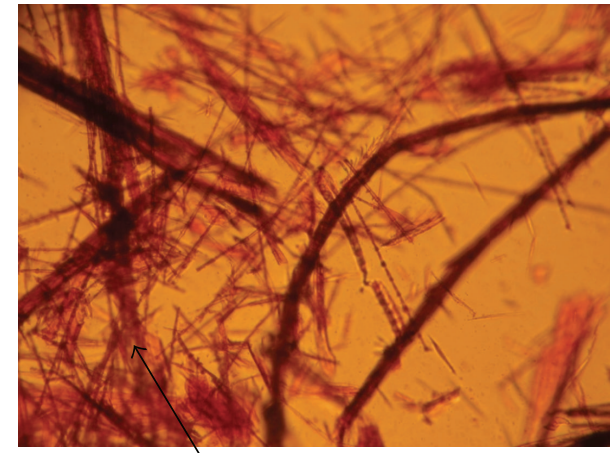

Degraded barbules

(b)

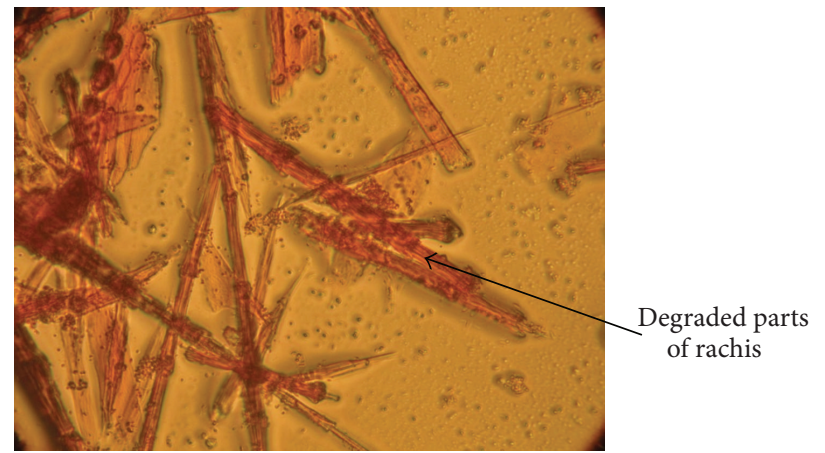

(c)

Figure 3: Microscopic observation of untreated (control) and degraded chicken feathers. (a) Untreated chicken feather (control), (b) feather after $24 \mathrm{~h}$ of degradation showing degradation of barbs (indicated by arrows), and (c) feather after $72 \mathrm{~h}$ of incubation showing degradation of rachis (indicated by arrows).

incomplete and after 7 days of incubation $80 \%$ of feathers were degraded. During the course of degradation at each concentration, cell growth, soluble protein, and keratinase activity were estimated (Figures $4(\mathrm{a}), 4(\mathrm{~b})$, and $4(\mathrm{c})$ ). It was observed that at concentration of $0.1,0.5$, and $1.0 \%$ feathers, the maximum concentration of soluble protein observed was $171.8 \pm 18.3 \mu \mathrm{g} / \mathrm{mL}$ after 3 day, $344.1 \pm 11.8 \mu \mathrm{g} / \mathrm{mL}$ after
5 day, and $480.8 \pm 17.1 \mu \mathrm{g} / \mathrm{mL}$ after 5 days of incubation. It was notable that the highest amount of soluble protein was observed during exponential phase of growth at each concentration. Similarly, keratinase activity also varied in the presence of different concentration of feathers. Maximum keratinase activity was $7.2 \pm 0.15 \mathrm{U} / \mathrm{mL}$ at concentration of $0.1 \%$ feathers, $11.8 \pm 0.2 \mathrm{U} / \mathrm{mL}$ in the presence of $0.5 \%$ 


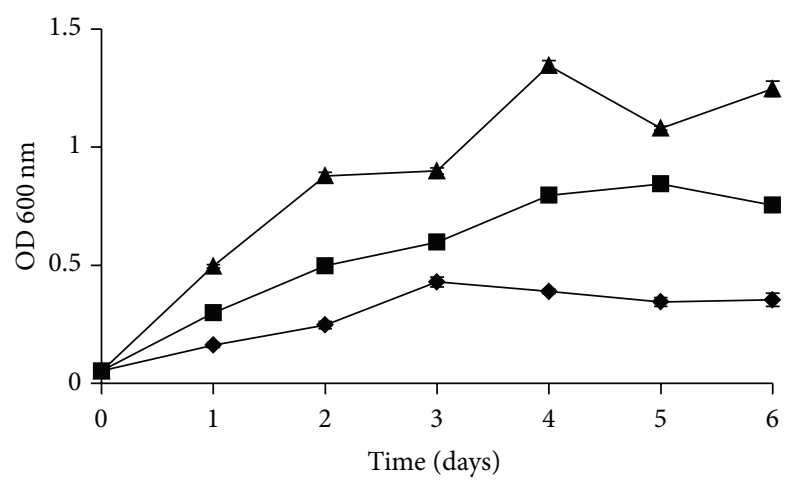

(a)

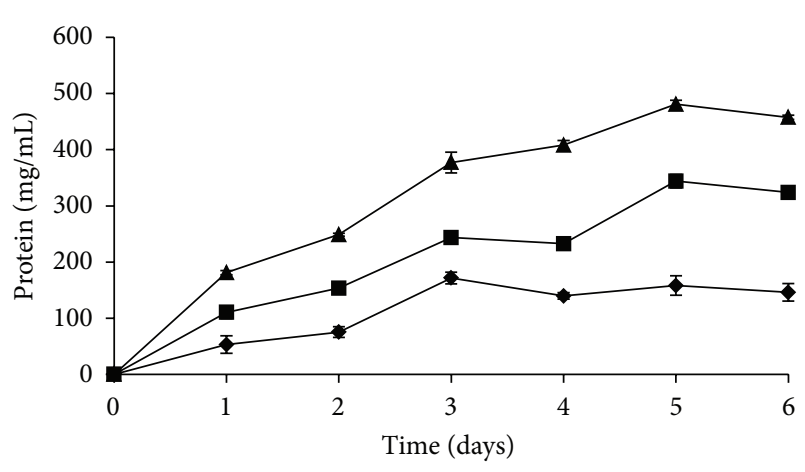

(b)

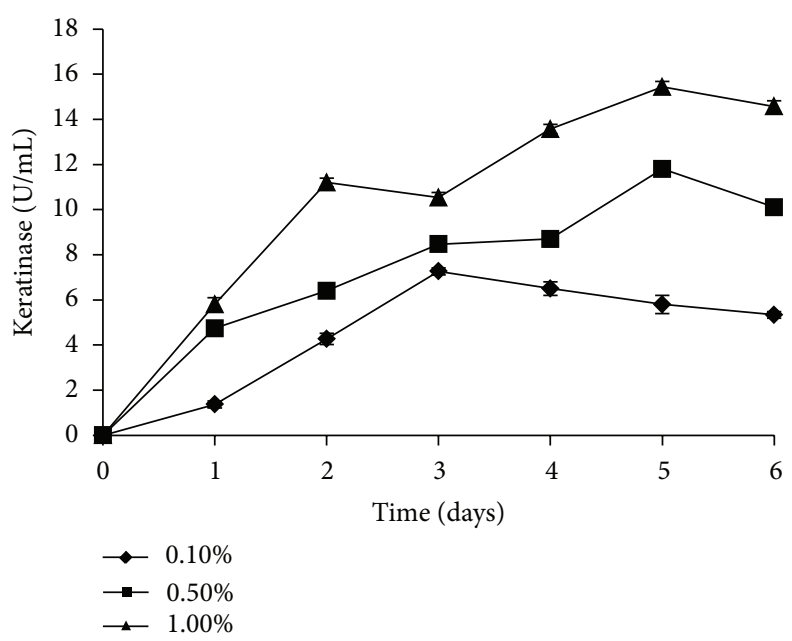

(c)

Figure 4: Time course study of growth and feather degradation by P. aeruginosa strain SDS3 on FMB supplemented with $0.1,0.5$, and $1 \%$ chicken feathers, incubated at $150 \mathrm{rpm}, 30^{\circ} \mathrm{C}$. (a) Time course study of growth, (b) soluble protein, and (c) keratinase production. The result is represented as mean \pm standard deviation of three independent experiments.

feathers, and $15.4 \pm 0.25 \mathrm{U} / \mathrm{mL}$ in the presence of $1.0 \%$ feathers, respectively. It was observed that the amount of soluble protein increased and decreased during the course of growth at each concentration. At early phase of growth, the amount of soluble protein was low at each concentration suggesting metabolism of proteins as a source of carbon and nitrogen by the strain SDS3. These results are in agreement with previous reports $[24,28]$, where maximum production was observed during exponential phase of growth, and amount of keratinases produced was proportional to the amount of substrate.

\subsection{Effect of Various Carbon and Nitrogen Sources on Soluble} Protein and Keratinase Production. Production of keratinases is usually regulated by nutritional status of growth medium. In most of the cases, it is upregulated by nutrient limitation and downregulated by nutrient availability [3]. Recent studies suggest upregulation of keratinase activity by various carbon and nitrogen sources [25]. Thus, an attempt was made to study the effect of various carbon and nitrogen sources on keratinase activity. Effect of all the carbon sources tested for keratinase activity is shown in Table 1. Malt extract and starch showed stimulatory effect on keratin degradation. The highest effect was shown by malt extract and starch, where 1.21-fold increase in keratinase activity and 1.25-fold increase in the amount of soluble proteins were observed in the presence of malt extract and 1.22-fold increase in the amount of soluble protein and 1.02 times increase in keratinase activity were observed in presence of starch. All other carbon source used in the present study showed inhibitory effect on keratin degradation, even though cell growth was high as compared to control.

Among different nitrogen sources used (Table 2), stimulatory effect was observed in complex nitrogen sources such as beef extract, tryptone, yeast extract, and skim milk. The highest activation was observed in the presence of beef extract and tryptone. In the presence of beef extract, 1.53fold increase in amount of soluble protein and 1.81-fold increase in the amount of keratinase were observed, whereas in the presence of tryptone, 1.31-fold increase in the amount of soluble protein and 1.77-fold increase in keratinase were observed. Simple nitrogen sources had an inhibitory effect on keratin degradation. These results are in accordance with 
TABLE 1: Effect of carbon sources on growth, soluble protein, and keratinase activity.

\begin{tabular}{|c|c|c|c|}
\hline Carbon source $(0.1 \% \mathrm{w} / \mathrm{v})$ & Growth $(\mathrm{OD} 600 \mathrm{~nm})^{\mathrm{a}}$ & Protein $(\mu \mathrm{g} / \mathrm{mL})^{\mathrm{a}}$ & Keratinase activity $(\mathrm{U} / \mathrm{mL})^{\mathrm{a}}$ \\
\hline Control & $0.282 \pm 0.015$ & $139.7 \pm 9.7$ & $7.1 \pm 0.3$ \\
\hline Glycerol & $0.249 \pm 0.011$ & $102.9 \pm 4.9$ & $6.4 \pm 0.32$ \\
\hline Fructose & $0.214 \pm 0.007$ & $124.2 \pm 4.6$ & $6.8 \pm 0.26$ \\
\hline Galactose & $0.243 \pm 0.012$ & $60.2 \pm 4.6$ & $5.2 \pm 0.25$ \\
\hline Sucrose & $0.506 \pm 0.014$ & $79.4 \pm 3.4$ & $6.5 \pm 0.3$ \\
\hline Glucose & $0.164 \pm 0.022$ & $68.4 \pm 2.6$ & $4.5 \pm 0.24$ \\
\hline Maltose & $0.211 \pm 0.013$ & $130.8 \pm 7.2$ & $7.5 \pm 0.35$ \\
\hline Mannitol & $0.32 \pm 0.019$ & $109.5 \pm 7.9$ & $5.5 \pm 0.21$ \\
\hline Malt extract & $0.237 \pm 0.018$ & $175.3 \pm 9.4^{*}$ & $8.6 \pm 0.31^{*}$ \\
\hline Lactose & $0.319 \pm 0.006$ & $128.7 \pm 9.1$ & $6.3 \pm 0.32$ \\
\hline Starch & $0.28 \pm 0.011$ & $169.7 \pm 8.5^{*}$ & $8.0 \pm 0.14^{*}$ \\
\hline
\end{tabular}

${ }^{\mathrm{a}}$ Values are mean \pm standard deviation of three independent experiments.

${ }^{*}$ Significantly different from control at $95 \%$ confidence level.

TABLE 2: Effect of nitrogen sources on growth, soluble protein, and keratinase activity.

\begin{tabular}{|c|c|c|c|}
\hline Nitrogen source $(0.05 \% \mathrm{w} / \mathrm{v})$ & Growth $(\mathrm{OD} 600 \mathrm{~nm})^{\mathrm{a}}$ & Protein $(\mu \mathrm{g} / \mathrm{mL})^{\mathrm{a}}$ & Keratinase activity $(\mathrm{U} / \mathrm{mL})^{\mathrm{a}}$ \\
\hline Control & $0.304 \pm 0.011$ & $142.7 \pm 2.3$ & $7.4 \pm 0.4$ \\
\hline Casein & $0.352 \pm 0.014$ & $112.3 \pm 3.1$ & $7.5 \pm 0.3$ \\
\hline Yeast extract & $0.326 \pm 0.012$ & $160.6 \pm 4.4$ & $12.5 \pm 0.34^{*}$ \\
\hline Urea & $0.394 \pm 0.018$ & $158.9 \pm 4.1$ & $12.8 \pm 0.4^{*}$ \\
\hline Ammonium sulfate & $0.202 \pm 0.014$ & $87.6 \pm 4.0$ & $5.3 \pm 0.31$ \\
\hline Potassium nitrate & $0.271 \pm 0.014$ & $65.8 \pm 2.6$ & $7.5 \pm 0.33$ \\
\hline Ammonium chloride & $0.294 \pm 0.016$ & $63.01 \pm 2.9$ & $7.1 \pm 0.26$ \\
\hline $\mathrm{NH}_{4} \mathrm{H}_{2} \mathrm{PO}_{4}$ & $0.295 \pm 0.0009$ & $112.3 \pm 5.8$ & $6.5 \pm 0.15$ \\
\hline Ammonium nitrate & $0.275 \pm 0.010$ & $139.9 \pm 5.2$ & $6.9 \pm 0.31$ \\
\hline Sodium nitrite & $0.255 \pm 0.011$ & $79.4 \pm 2.1$ & $5.8 \pm 0.21$ \\
\hline Sodium nitrate & $0.277 \pm 0.012$ & $87.6 \pm 2.8$ & $6.4 \pm 0.24$ \\
\hline Skim milk & $0.319 \pm 0.012$ & $168.2 \pm 3.7^{*}$ & $9.6 \pm 0.34^{*}$ \\
\hline Tryptone & $0.459 \pm 0.018$ & $187.3 \pm 4.2^{*}$ & $13.2 \pm 0.36^{*}$ \\
\hline Beef extract & $0.319 \pm 0.007$ & $219.2 \pm 7.5^{*}$ & $13.4 \pm 0.27^{*}$ \\
\hline
\end{tabular}

${ }^{\mathrm{a}}$ Values are mean \pm standard deviation of three independent experiments.

${ }^{*}$ Significantly different from control at $95 \%$ confidence level.

previous reports, where keratinase production was downregulated in the presence of simple nitrogen sources [25]. These reports suggest that keratinase production is inducible and is regulated by the availability of nutrients and also it is negatively regulated by the presence of nutrients. Contrary to these findings, keratinase production was increased in the presence of complex nitrogen sources such as yeast extract and beef extract. Similar results have been reported by Son et al. [29] in B. pumilis, where keratinolytic activity was upregulated by yeast extract and was downregulated by glucose and simple nitrogen sources. It is assumed that amino acids and short peptides present in complex nitrogen sources exert a stimulatory effect on keratinase production.

3.4. Electricity Production by Employing MFC. The highest production of soluble protein and keratinase was observed in the presence of $1 \%$ chicken feathers and effect of carbon and nitrogen sources showed that the highest stimulation was observed in the presence of $0.05 \%$ beef extract. Thus, MFC was fed with $1 \%$ chicken feathers supplemented with $0.05 \%$ beef extract. At the start of MFC operation, an initial potential of $8 \mathrm{mV}$ was observed. This potential can be due to the difference in potential between anode and cathode chambers. With time, a gradual increase in voltage was observed. This increase was clearly due to microbial growth and metabolism. After 8 days of incubation, a voltage of $105 \mathrm{mV}$ was achieved. The voltage reached its peak ( $141 \mathrm{mV})$ after 14 days of incubation; it was stable up to 24 days and thereafter showed gradual decrease (Figure 5). Power and current density also followed a similar pattern. Maximum power density of $1206.78 \mathrm{~mW} / \mathrm{m}^{2}$ and maximum current density of $8.6 \mathrm{~mA} / \mathrm{m}^{2}$ were observed after 14 days of MFC operation (Figure 6). Our results are in accordance with Kaewkannetra et al. [30], where a maximum power density of $1771 \mathrm{~mW} / \mathrm{m}^{2}$ was observed when cassava mill wastewater was used as substrate. It is clear from Figure 5 that electricity production occurs in three distinct phases, the ascending, stationary, and declining phase [30]. In the present study, the ascending phase was of 8 day incubation, 


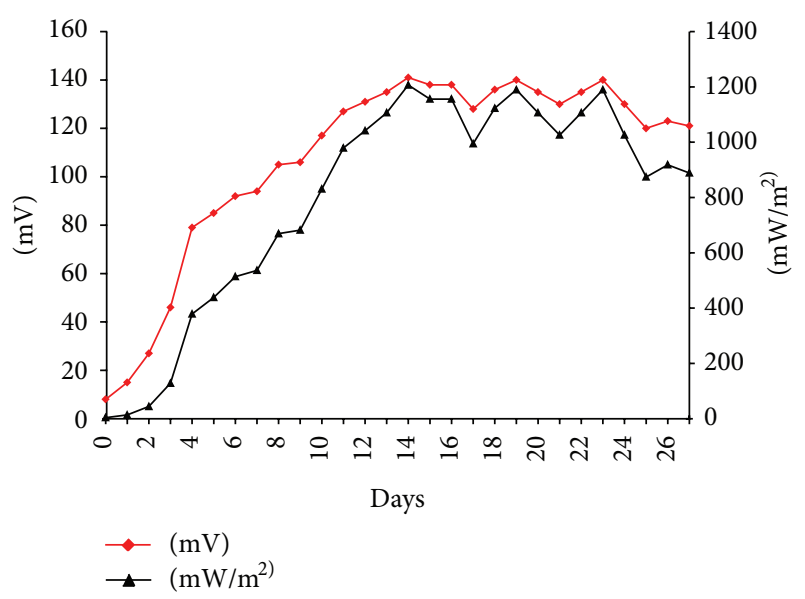

FIgURE 5: Time course variation in power density and voltage of MFC fed with $1.0 \%$ chicken feather and $0.05 \%$ beef extract as substrate; $P$. aeruginosa strain SDS3 was used as inoculum. MFC was incubated at $30^{\circ}$ in a BOD incubator.

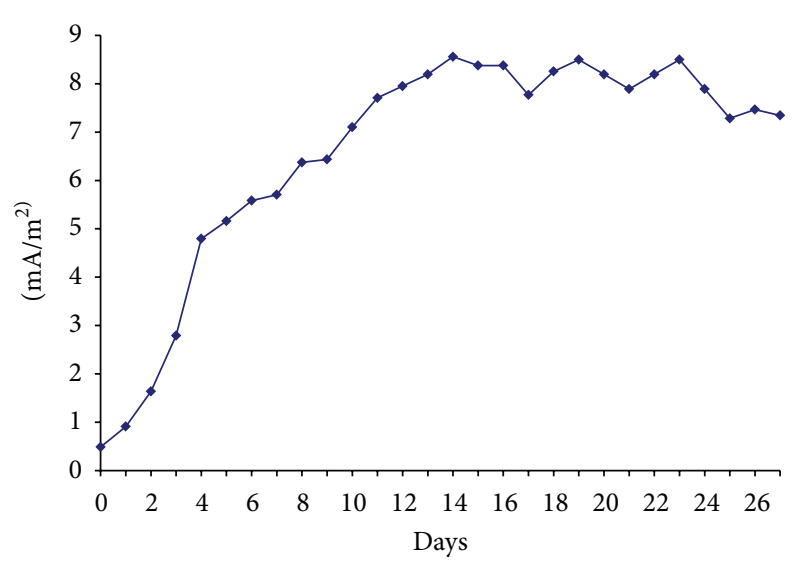

FIGURE 6: Time course variation in current density of MFC fed with $1.0 \%$ chicken feather and $0.05 \%$ beef extract as substrate; $P$. aeruginosa strain SDS3 was used as inoculum. MFC was incubated at $30^{\circ}$ in a $\mathrm{BOD}$ incubator.

stationary phase was 16 days, and declining phase was 4 days. These results clearly demonstrate that this MFC setup is feasible for electricity production as the stationary phase was 16 days long. Many studies have demonstrated that the success of MFC operation depends upon the duration of stationary phase $[16,17]$. If the duration is long then MFC is practically feasible. Therefore, our results clearly demonstrate that chicken feathers can be employed in MFC for electricity generation. Polarization curve was drawn to access the relation between resistance and current during fuel cell operation (Figure 7). Polarization curve was obtained at different resistance $(33 \Omega-80 \mathrm{k} \Omega$ ), which showed that current density and power density decreased with increasing resistance. Voltage showed an increase with increasing resistance and showed rapid stabilization at higher resistance. This behavior is typical of a MFC, which has been corroborated with previous studies [11, 31].

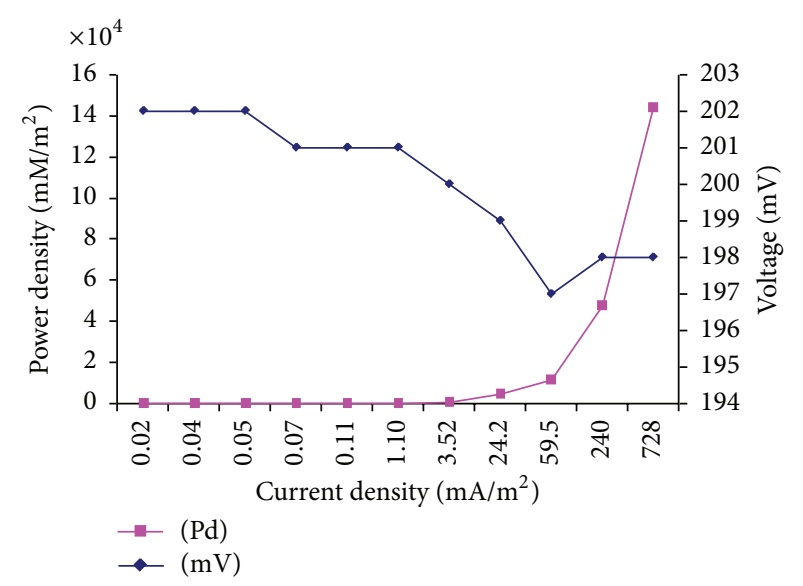

FIGURE 7: Polarization curve generated by measuring voltage and current at different resistance during the stable performance of MFC.

In this study, strain SDS3 was employed for metabolism of chicken feathers. Strain SDS3 shows a slow rate of feather metabolism as compared to rapid feather degrading strain KS-1 [27]. This suggests that the use of strain SDS3 in MFC is advantageous because a slow rate of feather degradation will eventually increase the duration of stationary phase of MFC and will lead to greater electricity production over a large time period.

\section{Conclusions}

The present study clearly indicates that strain SDS3 can metabolize chicken feathers as a source of carbon and nitrogen. It was observed that strain SDS3 completely metabolized 0.1 and $0.5 \%$ chicken feathers. However, at $1.0 \%$ concentration, only $80 \%(\mathrm{w} / \mathrm{v})$ feathers were metabolized. High amounts of soluble protein and keratinase activity was observed at $1.0 \%$ feather concentration. The complex carbon and nitrogen sources such as tryptone, beef extract, and starch stimulated feather degradation; however, simple carbon and nitrogen sources were inhibitory to feather degradation. Chicken feathers were employed as a substrate in MFC for electricity generation. Results indicated that maximum power density of $1206.78 \mathrm{~mW} / \mathrm{m}^{2}$ and maximum current density of $8.6 \mathrm{~mA} / \mathrm{m}^{2}$ were observed after 14 days of MFC operation and were stable for 16 days. These results clearly indicate that chicken feathers can be successfully employed for electricity generation using MFC technology. This is the first report of successful utilization of chicken feathers as a substrate in MFC for electricity production.

\section{Abbreviations}

MFC: $\quad$ Microbial fuel cell

$\mathrm{C} / \mathrm{N}$ ratio: Carbon/nitrogen ratio

SDS: $\quad$ Sodium dodecyl sulfate

PBM: $\quad$ Phosphate buffered medium 
FMB: $\quad$ Feather meal broth

FMA: $\quad$ Feather meal agar

TTC: $\quad$ 2, 3, 5-Triphenyl tetrazolium chloride

LB medium: Luria Bertani medium

BSA: $\quad$ Bovine serum albumin

TCA: $\quad$ Trichloroacetic acid

BOD: Biological oxygen demand.

\section{Conflict of Interests}

The authors declare that they do not have any conflict of interests.

\section{References}

[1] A. A. Khardenavis, A. Kapley, and H. J. Purohit, "Processing of poultry feathers by alkaline keratin hydrolyzing enzyme from Serratia sp. HPC 1383," Waste Management, vol. 29, no. 4, pp. 1409-1415, 2009.

[2] L. Manczinger, M. Rozs, C. Vágvölgyi, and F. Kevei, "Isolation and characterization of a new keratinolytic Bacillus licheniformis strain," World Journal of Microbiology and Biotechnology, vol. 19, no. 1, pp. 35-39, 2003.

[3] N. M. R. Da Gioppo, F. G. Moreira-Gasparin, A. M. Costa, A. M. Alexandrino, C. G. M. De Souza, and R. M. Peralta, "Influence of the carbon and nitrogen sources on keratinase production by Myrothecium verrucaria in submerged and solid state cultures," Journal of Industrial Microbiology and Biotechnology, vol. 36, no. 5, pp. 705-711, 2009.

[4] R. Gupta and P. Ramnani, "Microbial keratinases and their prospective applications: an overview," Applied Microbiology and Biotechnology, vol. 70, no. 1, pp. 21-33, 2006.

[5] B. S. Harrap and E. F. Woods, "Soluble derivatives of feather keratin. 1. Isolation, fractionation and amino acid composition," Biochemical Journal, vol. 92, no. 1, pp. 8-18, 1964.

[6] A. A. Onifade, N. A. Al-Sane, A. A. Al-Musallam, and S. AlZarban, "A review: potentials for biotechnological applications of keratin-degrading microorganisms and their enzymes for nutritional improvement of feathers and other keratins as livestock feed resources," Bioresource Technology, vol. 66, no. 1, pp. 1-11, 1998.

[7] M. C. Papadopoulos, A. R. El Boushy, A. E. Roodbeen, and E. H. Ketelaars, "Effects of processing time and moisture content on amino acid composition and nitrogen characteristics of feather meal," Animal Feed Science and Technology, vol. 14, no. 3-4, pp. 279-290, 1986.

[8] C. G. Cai, B. G. Lou, and X. D. Zheng, "Keratinase production and keratin degradation by a mutant strain of Bacillus subtilis," Journal of Zhejiang University B, vol. 9, no. 1, pp. 60-67, 2008.

[9] A. Hadas and L. Kautsky, "Feather meal, a semi-slow-release nitrogen fertilizer for organic farming," Fertilizer Research, vol. 38, no. 2, pp. 165-170, 1994.

[10] B. E. Logan, "Biologically extracting energy from wastewater: biohydrogen production and microbial fuel cells," Environmental Science and Technology, vol. 38, no. 9, pp. 160-167, 2004.

[11] B. E. Logan and J. M. Regan, "Microbial fuel cells: challenges and applications," Environmental Science and Technology, vol. 40, no. 17, pp. 5172-5180, 2006.

[12] Y. Lin and S. Tanaka, "Ethanol fermentation from biomass resources: current state and prospects," Applied Microbiology and Biotechnology, vol. 69, no. 6, pp. 627-642, 2006.
[13] D. Saaris, Y. Kotseridis, M. Linga, M. Galiotou-Panayotou, and S. Papanikolaou, "Enhanced ethanol production, volatile compound biosynthesis and fungicide removal during growth of a newly isolated Saccharomyces cerevisiae strain on enriched pasteurized grape musts," Engineering in Life Sciences, vol. 9, no. 1, pp. 29-37, 2009.

[14] K. Rabaey, W. Ossieur, M. Verhaege, and W. Verstraete, "Continuous microbial fuel cells convert carbohydrates to electricity," Water Science and Technology, vol. 52, no. 1-2, pp. 515-523, 2005.

[15] B. Min, J. R. Kim, S. E. Oh, J. M. Regan, and B. E. Logan, "Electricity generation from swine wastewater using microbial fuel cells," Water Research, vol. 39, no. 20, pp. 4961-4968, 2005.

[16] S. A. Patil, V. P. Surakasi, S. Koul et al., "Electricity generation using chocolate industry wastewater and its treatment in activated sludge based microbial fuel cell and analysis of developed microbial community in the anode chamber," Bioresource Technology, vol. 100, no. 21, pp. 5132-5139, 2009.

[17] K. P. Katuri, A. Enright, V. O’Flaherty, and D. Leech, "Microbial analysis of anodic biofilm in a microbial fuel cell using slaughterhouse wastewater," Bioelectrochemistry, vol. 87, pp. 164-171, 2012.

[18] V. Chaturvedi and A. Kumar, "Diversity of culturable sodium dodecyl sulfate (SDS) degrading bacteria isolated from detergent contaminated ponds situated in Varanasi city, India," International Biodeterioration and Biodegradation, vol. 65, no. 7, pp. 961-971, 2011.

[19] E. Bach, D. J. Daroit, A. P. F. Corrêa, and A. Brandelli, "Production and properties of keratinolytic proteases from three novel Gram-negative feather-degrading bacteria isolated from Brazilian soils," Biodegradation, vol. 22, no. 6, pp. 11911201, 2011.

[20] A. De Logu, P. Uda, M. L. Pellerano, M. C. Pusceddu, B. Saddi, and M. L. Schivo, "Comparison of two rapid colorimetric methods for determining resistance of Mycobacterium tuberculosis to rifampin, isoniazid, and streptomycin in liquid medium," European Journal of Clinical Microbiology and Infectious Diseases, vol. 20, no. 1, pp. 33-39, 2001.

[21] M. M. Bradford, "A rapid and sensitive method for the quantitation of microgram quantities of protein utilizing the principle of protein dye binding," Analytical Biochemistry, vol. 72, no. 1-2, pp. 248-254, 1976.

[22] K. Wawrzkiewicz, J. Lobarzewski, and T. Wolski, "Intracellular keratinase of Trichophyton gallinae," Journal of Medical and Veterinary Mycology, vol. 25, no. 4, pp. 261-268, 1987.

[23] R. M. Tomarelli, J. Charney, and M. L. Harding, "The use of azoalbumin as a substrate in the colorimetric determination," The Journal of Laboratory and Clinical Medicine, vol. 34, no. 3, pp. 428-433, 1949.

[24] D. J. Daroit, A. P. F. Corrêa, and A. Brandelli, "Keratinolytic potential of a novel Bacillus sp. P45 isolated from the Amazon basin fish Piaractus mesopotamicus," International Biodeterioration and Biodegradation, vol. 63, no. 3, pp. 358-363, 2009.

[25] J. H. Jeong, Y. D. Jeon, O. M. Lee et al., "Characterization of a multifunctional feather-degrading Bacillus subtilis isolated from forest soil," Biodegradation, vol. 21, no. 6, pp. 1029-1040, 2010.

[26] B. Hou, Y. Hu, and J. Sun, "Performance and microbial diversity of microbial fuel cells coupled with different cathode types during simultaneous azo dye decolorization and electricity generation," Bioresource Technology, vol. 111, pp. 105-110, 2012. 
[27] R. Sharma and R. Gupta, "Substrate specificity characterization of a thermostable keratinase from Pseudomonas aeruginosa KS1," Journal of Industrial Microbiology and Biotechnology, vol. 37, no. 8, pp. 785-792, 2010.

[28] A. P. F. Corrêa, D. J. Daroit, and A. Brandelli, "Characterization of a keratinase produced by Bacillus sp. P7 isolated from an Amazonian environment," International Biodeterioration and Biodegradation, vol. 64, no. 1, pp. 1-6, 2010.

[29] H. J. Son, H. C. Park, H. S. Kim, and C. Y. Lee, "Nutritional regulation of keratinolytic activity in Bacillus pumilis," Biotechnology Letters, vol. 30, no. 3, pp. 461-465, 2008.

[30] P. Kaewkannetra, T. Imai, F. J. Garcia-Garcia, and T. Y. Chiu, "Cyanide removal from cassava mill wastewater using Azotobactor vinelandii TISTR 1094 with mixed microorganisms in activated sludge treatment system," Journal of Hazardous Materials, vol. 172, no. 1, pp. 224-228, 2009.

[31] S. Venkata Mohan, R. Saravanan, S. V. Raghavulu, G. Mohanakrishna, and P. N. Sarma, "Bioelectricity production from wastewater treatment in dual chambered microbial fuel cell (MFC) using selectively enriched mixed microflora: effect of catholyte," Bioresource Technology, vol. 99, no. 3, pp. 596-603, 2008. 

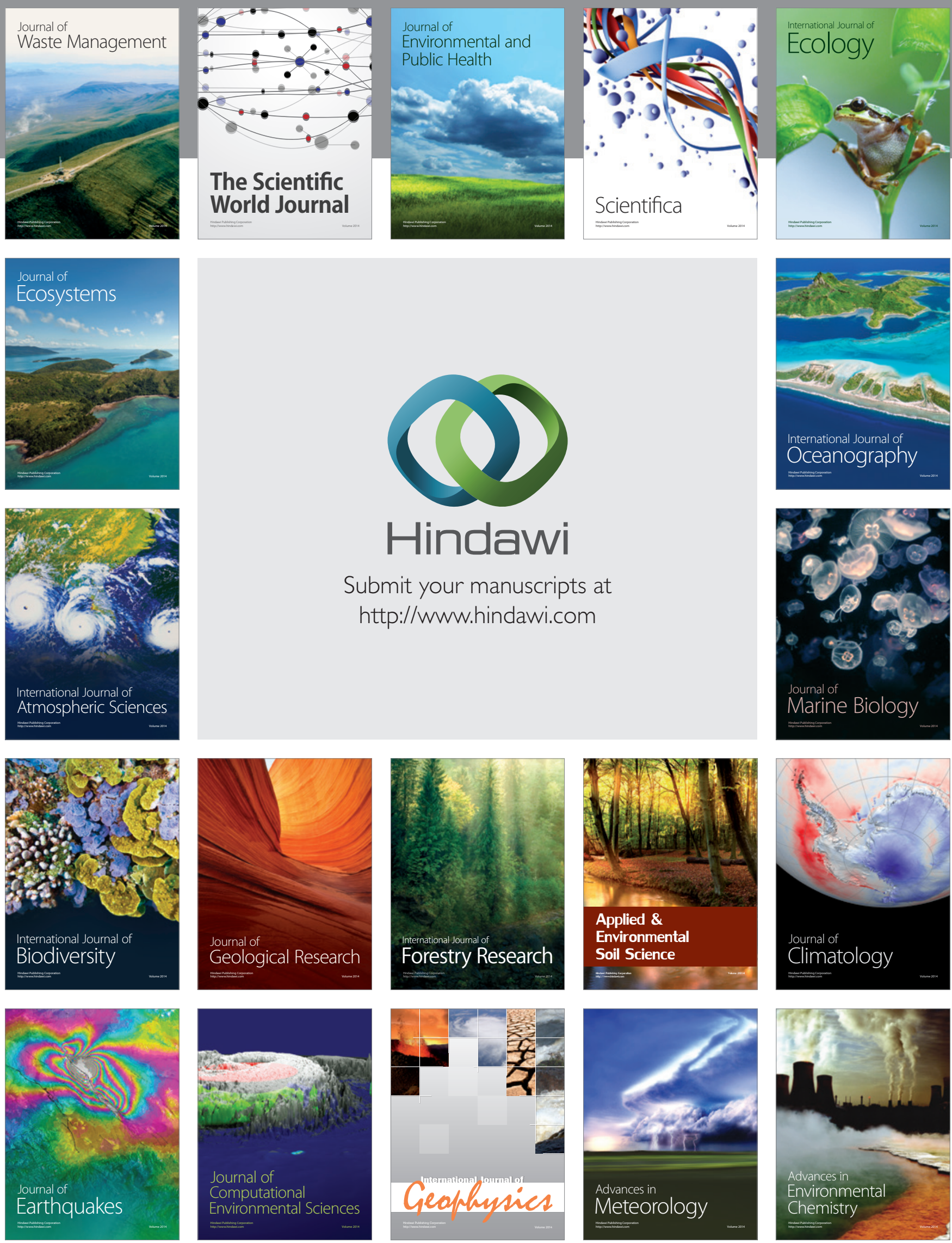